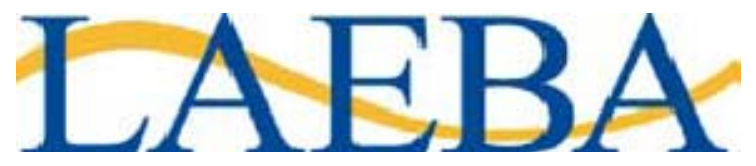

Latin America/Caribbean and Asia/Pacific Economics and Business Association

An initiative of the Inter-American Development Bank and the Asian Development Bank Institute

\author{
Third LAEBA Annual Meeting \\ Seoul, South Korea - November 16, 2006
}

\title{
Meeting the MDG Water Taraget in Asia: The role of regional co-operation
}

\section{P. B. Anand - Bradford Centre for International Development - University of Bradford}

Sponsored by

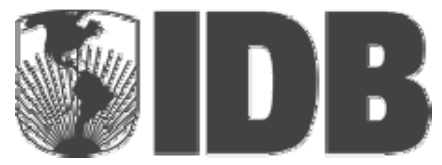

Inter-American Development Bank Integration and Trade Sector

Institute for the Integration of Latin American and the Caribbean (INTAL)

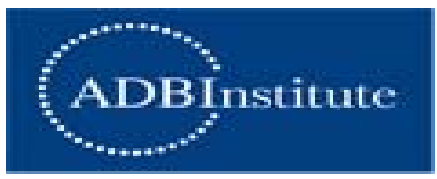




\section{LAEBA 2006 Third Annual Meeting}

An initiative of the Inter-American Development Bank and

The Asian Development Bank Institute

\section{Regional Integration and Regional Cooperation in Asia and Latin America: The Role of Regional Infrastructure}

Seoul, Korea, November 16-17, 2006

\section{Meeting the MDG Water Target in Asia: The Role of regional co- operation}

\section{P.B.Anand}

Senior Lecturer, Bradford Centre for International Development

University of Bradford

Email: p.b.anand@bradford.ac.uk

\section{Summary}

This paper focuses on access to water and sanitation related to the Millennium Development Goal 7. Asian region contains some of the top achievers in improving access to water and sanitation and also some of the nations with least improvement. Based on an analysis of data from WHO-UNICEF and other assessments, this research attempts to (a) forecast progress with target 10 for countries in the Asian region; and (b) examine and identify the role of institutional and policy variables such as the role of aid for water sector, water sector policy reforms, and institutional factors related to water utilities in contributing to the MDG target of improving access to water and sanitation. On the basis of these, the paper aims to identify issues for regional co-operation.

Key words: Water, sanitation, Millennium Development Goals

The views expressed in this paper are the views of the authors and do not necessarily reflect the views of policies of the Asian Development Bank (ADB), or its Board of Directors, or the governments they represent. ADBI does not guarantee the accuracy of the data included in this paper and accepts no responsibility for any consequences of their use. Terminology used may not necessarily be consistent with ADB official terms. 


\section{Meeting the MDG Water Target in Asia: The Role of regional co- operation}

\section{Introduction}

Access to water is a high priority policy issue from both human development and human security perspectives. Lack of access to water and sanitation is an important characteristic of poverty. This has been recognised, for instance, in the construction of Human Poverty Index. Improving access to water and sanitation has a significant influence on decreasing the disease burden due to diarrhoeal and other water-related health risks and on improving overall quality of life. In recognition of these factors, the Millennium Development Goals include the aspiration to reduce by half the proportion of population without access to water and sanitation by 2015 .

As per WHO-UNICEF (2004) assessment, globally, 77 per cent of population had access to water in 1990. This proportion has increased to 83 per cent in 2002, thus, on track to achieve the target of halving the proportion of population without safe access by 2015. Much of this global increase comes from very significant improvement in access to water in India and China. However, that report also notes that in 2002, two thirds of the 1.1 billion people lacking access to an improved source of water were also in Asia. For example, among the six countries world-wide with the lowest proportion of population having access to water and sanitation in 2002, three countries ${ }^{1}$ were in Asia. The Millennium Task Force (UNDP,2005) report highlights a number of factors why it is important to pursue the water and sanitation targets. Other studies, notably, Hutton and Haller (2004) and Rijsberman (2004) argue that water and sanitation investments should be considered a priority from economic point of view too because benefit cost ratios are in excess of 2.0. The ADB (2006) study focuses on progress with target 10 in Asian countries and estimated the costs of three alternative policy packages based on packages and unit costs developed by Hutton and Haller.

\section{Aims and objectives:}

Against this background, I would like to examine the following research questions:

\footnotetext{
${ }^{1}$ Afghanistan, Cambodia, and Lao People's Democratic Republic.
} 
a. Based on progress between 1990 and 2002, which countries of the Asian region are likely to meet the water and sanitation targets of MDG7 and which countries are likely to miss these targets?

b. What role has aid played in improving access between 1990 and 2002? And if the effectiveness remains at a similar level, what is the magnitude of aid required for water and sanitation sector in Asian region to achieve the MDG target 10 ?

c. Which policy variables have a significant impact on improving access to water and sanitation? In particular, from the data available, what can we say about the role of technical infrastructure and 'hardware' in promoting access? For example, is there synergy between development of irrigation infrastructure and improving access to water and sanitation?

d. Is there a role for international co-operation and regional strategies in promoting access to water? To a large extent, water supply and sanitation are matters of domestic policy in countries. However, in relation to international water resources, as the Helsinki Rules and Seoul Rules emphasise, co-operation between nations is crucial.

e. What are the implications of these findings for both policy and further research? In particular, how can these findings help in improving targeting of water and sanitation investments to help achieve MDG target 10 ?

\section{Data and methodology:}

This study uses secondary data sources and published resources, namely, WHO-UNICEF (2004), FAO-Aquastat, World Bank privatisation database, OECD-CRS, and the Asian utilities data (McIntosh and Yniguez,1998). For issues under items $a, b$, and $c$ above, I will be mainly using such secondary data and regression analysis. With regard to issues under items $d$ and $e$ above, I would like to examine briefly using case studies and identify issues for policy and further research.

\section{Water and sanitation in Asia and the Pacific}

In a number of developing countries in Asia, over 80 per cent of population has access to improved sources of water in 2002. ADB (2006) study estimates that approximately 758 million people gained access to improved sources of water in the region since 1990. Despite this progress, some 670 million people in the region were without access to water as of 2002. With regard to sanitation, the ADB study noted that there has been 
little change between 1990 and 2002 in the proportion of population with access to sanitation. Nearly 2 billion out of 2.6 billion people world-wide were in the Asian region. Figure 1 below summarises the picture as of 2002. Most of the Asian countries are to the right of $60 \%$ coverage as far as water supply is concerned. However, access to sanitation remains a major challenge.

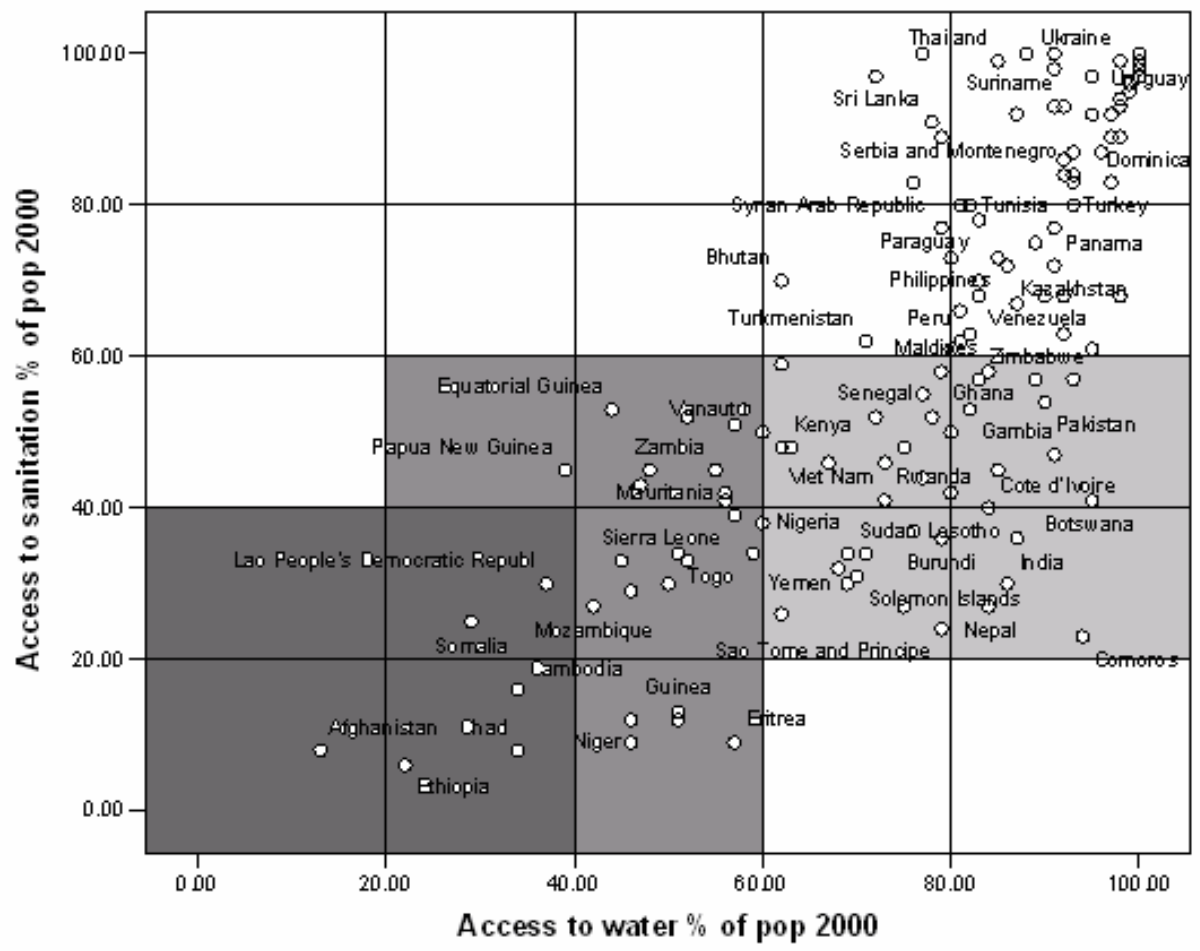

Figure 1: Access to water and sanitation (Source: Anand,2007)

Another message from this figure appears to be that though there is synergy in access to water and sanitation, countries seem to consider these in sequence with high priority accorded to improving access to water in the first instance and after this has been achieved, then improving access to sanitation in the second instance.

There is a positive and significant relationship between income per capita and proportion of population with access to water and sanitation. This is evident from figures 2 and 3 below. 


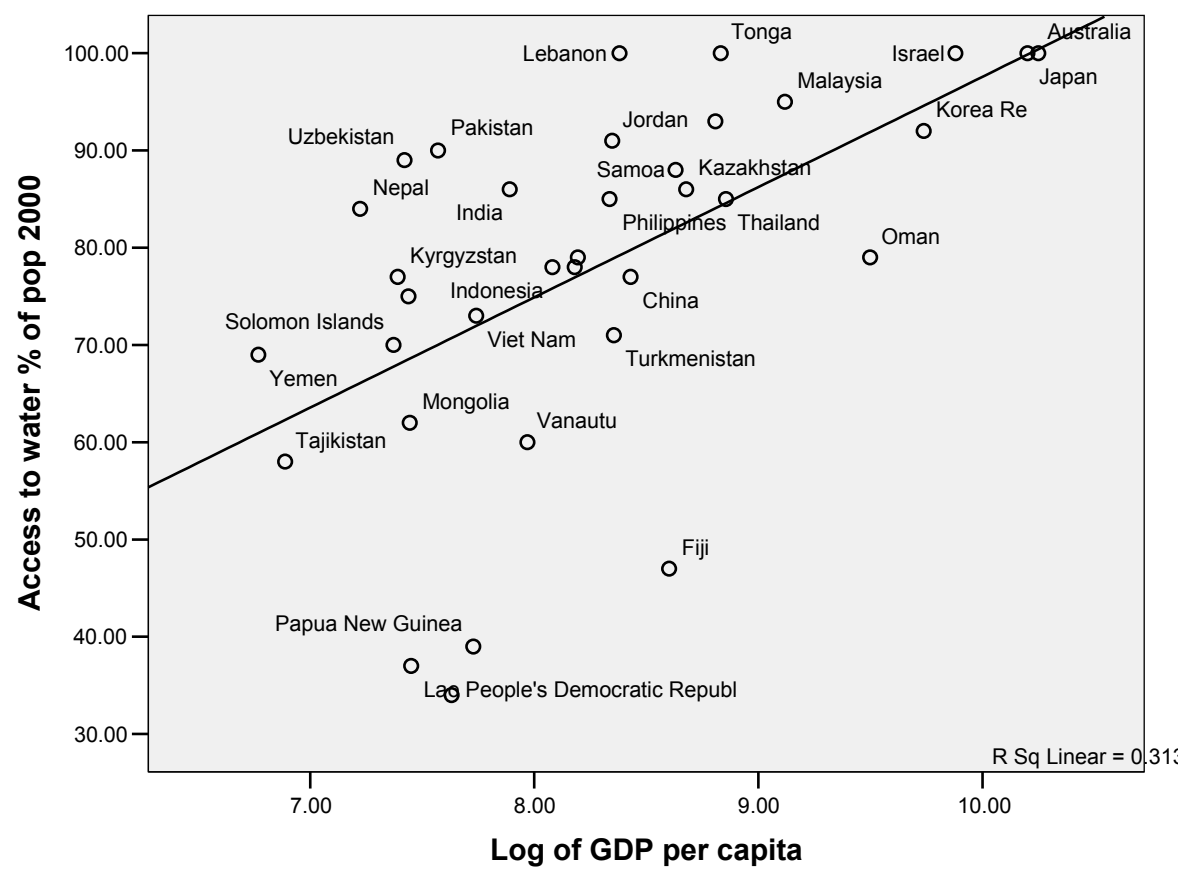

Figure 2: Per capita GDP and share of population with access to water in 2002

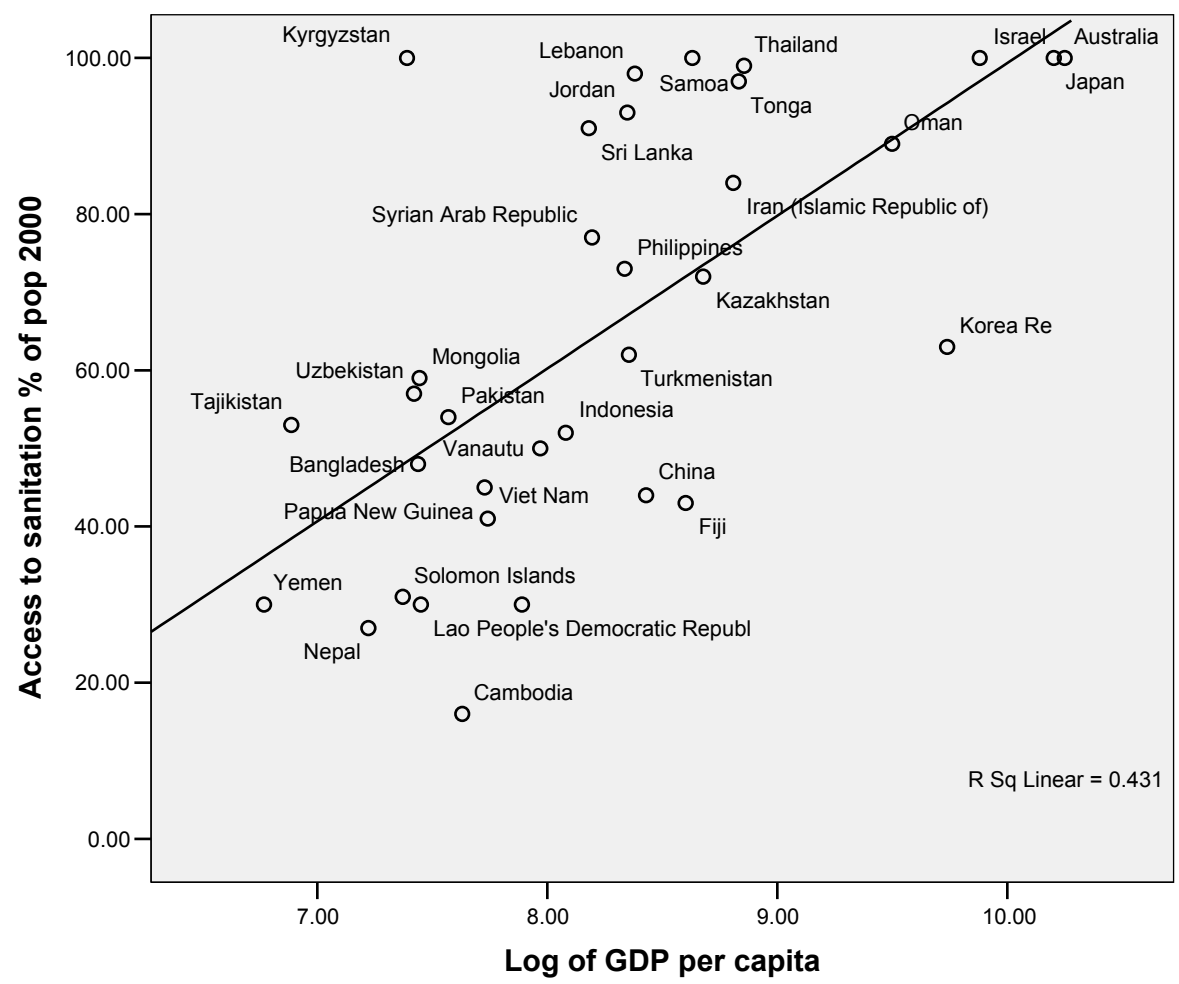

Figure 3: Per capita GDP and share of population with access to sanitation 2002 
Variation in the proportion of population with access to water or sanitation appears to be determined significantly by per capita GDP. This so-called 'environmental Kuznets curve' (EKC) explanation can lead to rather alarming policy recommendations. Does this mean that it is futile for countries to worry about access to water and sanitation? Are they better off focusing their energies in the pursuit of economic growth and let structural change take care of improving access? Does policy matter? Preliminary analysis suggests that while per capita GDP is significant, other policy variables may also be important. Among other things, GDP growth rate, population policy, aid per capita, and (control of) corruption seem to be important too.

With regard to water and sanitation, the starting point does matter and this means that it is a very big challenge for countries with little or limited water and sanitation infrastructure to begin with. Figure 4 below captures this aspect. The proportion of population with access to water / sanitation in 1990 is measured along the horizontal access; the corresponding figure for 2002 is shown on the vertical access. There is an enormous backlog with regard to sanitation, particularly in South and South East Asia. Even in countries such as India, Pakistan, and China which have made significant progress with regard to water, access to sanitation remains a major challenge. The estimated fit lines also help explain why countries increase water access first before dealing with sanitation: the slopes of the two lines suggest that expanding access to water is easier than increasing access to sanitation. 


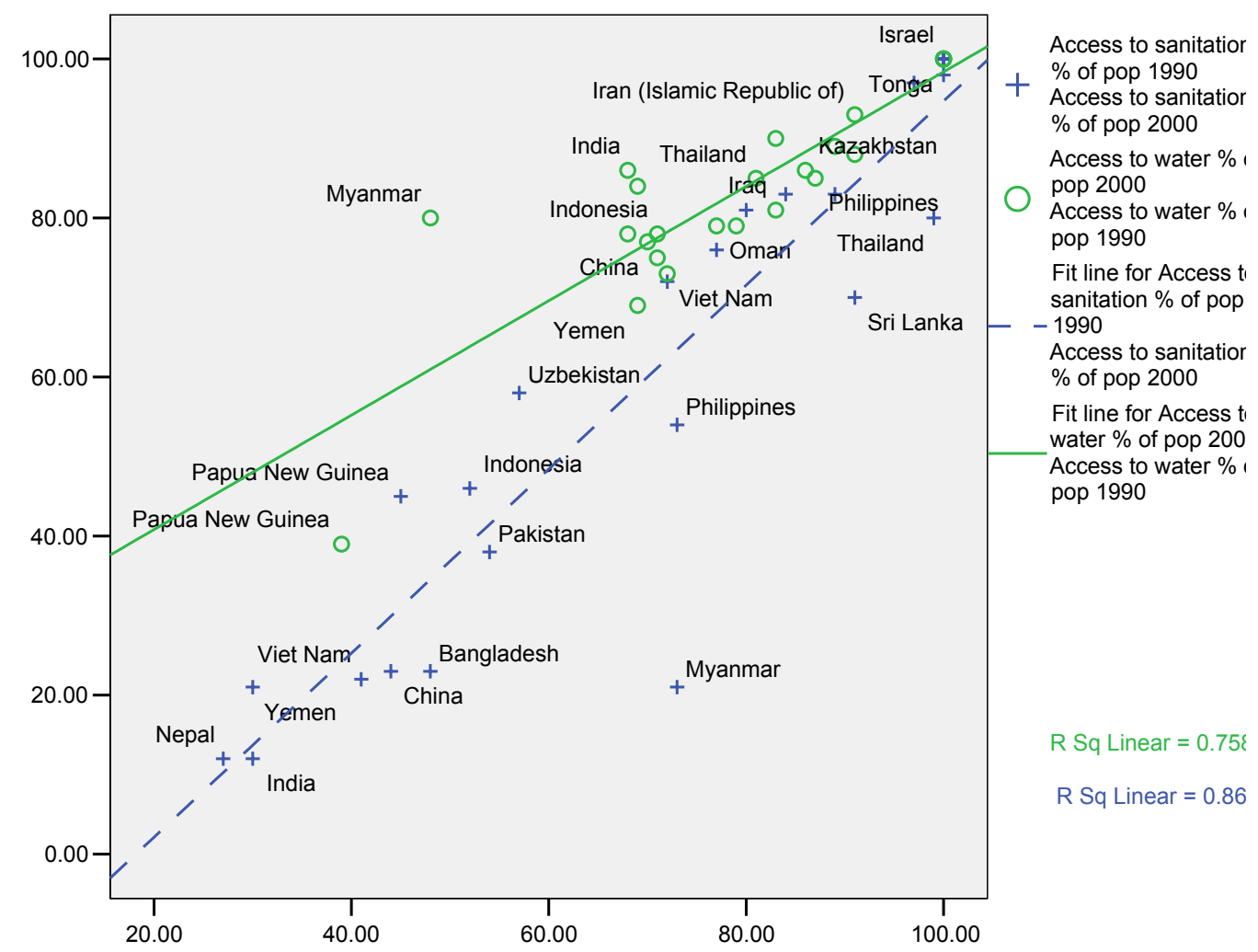

Figure 4: Access to water and sanitation in $1990 \mathrm{v}$ access to water and sanitation in 2002

Based on the discussion so far, Asian region countries seem to fall into one of the three categories, namely:

Group 1: countries with significantly high proportion of population ( $>60 \%$ ) having access to both water and sanitation (for example, Sri Lanka, Thailand, Oman, Iran, Syria, and Kazakhstan);

$>$ Group 2: countries where access to water has improved significantly but access to sanitation remains low (for example, India, Pakistan, Viet Nam and Nepal); and

$>$ Group 3: countries where access to both water and sanitation remains low (for example, Lao, Cambodia, Afghanistan).

The policy priority for the first group of countries is to sustain the progress already made and continue to provide access with the goal of reaching $100 \%$. The priority for the second group of countries is to maintain the pace of increasing access to water but simultaneously give high priority to sanitation also. The policy priority for the countries in third group is to pursue both of the targets as a high priority. 


\section{Forecasting progress}

Based on regression models, it is possible to forecast the likely proportion of population to have access to water and sanitation in a number of countries and compared this with the MDG target. From the results so far, it is clear that a significant number of countries will miss the water target and a large proportion of developing countries will miss the sanitation target.

Non-availability of data is a major hurdle in forecasting progress with regard to target 10 of the MDGs. Data is available from WHO-UNICEF joint monitoring programme for two points in time, namely, for 1990 and 2002. A small number of previous studies such as the interim assessment by Joint Monitoring Programme of the WHO-UNICEF (2004), UNDP (2004), and the $\operatorname{ADB}(2006)$ forecast progress based on the trend between 1990 and 2002. The basic methodology in these studies can be summarised as below.

Let the proportion of population with access to water in country $i$ at time $\mathrm{t} 1$ be $w_{i t 1}$ and at time $\mathrm{t} 2$ be $w_{i t 2}$. Thus, the progress made between years $\mathrm{t} 1$ and $t 2$ is:

$d w=w_{i t 2}-w_{i t 1}$

It is assumed that similar level of progress will be made between $t 2$ and $t 3$ (because $\mathrm{t} 3-\mathrm{t} 2=\mathrm{t} 2-\mathrm{t} 1$ ). On this basis, the proportion of population at the end of $\mathrm{t} 3$ is estimated as:

$w_{i t 3}=w_{i t 2}+d w$

The Millennium Development Goal target for this country is calculated on the basis of proportion of population lacking access to water in 2002.

$M D G=0.5^{*}\left(100-w_{i+2}\right)$

If the target is to be met, the country needs to achieve by 2015 (t3):

${ }^{e} w_{i+3}=w_{i+2}+M D G$

By comparing the estimated proportion of population with access, namely, $w_{i t 3}$ with the target of ${ }^{e} w_{i t 3}$, conclusions are drawn whether the target will be achieved or not. 
My estimation procedure differs with regard to equation 2. Instead of simply adding $d w$ to the figures related to 2002, I have used regression models. In the first instance, I try to estimate access to water in 2002 based on data for 1990 and other explanatory variables including per capita GDP, GDP growth rate, water resources per capita, health expenditure in GDP, population growth rate and so on for years between 1990-2000. In these models,

$w_{i t 2}=\alpha+\beta_{1} w_{i t 1}+\beta_{2} G D P_{i t 1}+\beta_{3} G D P g$ rowth ${ }_{i, t, t 2}+\beta_{4}$Health GDP $_{i t 1} \ldots$

Now, using the parameters from this model, the proportion of population with access to water in 2015 ( $w_{i+3}$ ) is estimated using relevant figures for other independent variables from the years 2000-2004. This method captures the structural relationship between economic performance and improvement in access to water and sanitation better than the WHOUNICEF method. Models W1, W2, and W3 relate to access to water; models $\mathrm{S} 1$ and $\mathrm{S} 2$ relate to access to sanitation. These regressions are reported in tables $\mathrm{A} 1$ and $\mathrm{A} 2$ in the appendix.

The forecast for Asia-Pacific countries based on models W2 and W3 with regard to water target is shown in table 1 . Similar results with regard to sanitation target are shown in table 2 below. 
Table 1: Forecast of progress with access to water 2015 using regression models W2 and W3

\begin{tabular}{|c|c|c|c|c|c|c|c|}
\hline Country & $\begin{array}{l}\text { Access } \\
\text { to } \\
\text { water } \\
\% \text { of } \\
\text { pop } \\
1990 \\
\end{array}$ & $\begin{array}{l}\text { Access } \\
\text { to } \\
\text { water } \\
\% \text { of } \\
\text { pop } \\
2000 \\
\end{array}$ & $\begin{array}{l}\text { Addl \% of } \\
\text { population } \\
\text { to be } \\
\text { provided } \\
\text { water to } \\
\text { meet MDG } \\
\text { (half of } 100 \\
\text { minus } \\
\text { wat2000) }\end{array}$ & $\begin{array}{l}\text { MDG \% of } \\
\text { population } \\
\text { with access } \\
\text { to water in } \\
2015= \\
\text { Access in } \\
2000+ \\
\text { IDTarget }\end{array}$ & $\begin{array}{l}\text { Projection1 } \\
\text { for } 2015 \\
\text { based on } \\
\text { model W1 }\end{array}$ & $\begin{array}{l}\text { Projection2 } \\
\text { for } 2015 \\
\text { based on } \\
\text { model W2 }\end{array}$ & $\begin{array}{l}\text { Gap } \\
\text { (Projec- } \\
\text { tion } 1 \\
\text { minus } \\
\text { MDG) }\end{array}$ \\
\hline Saudi Arabia & 90 & . & . & . & . & 97.62 & . \\
\hline Japan & 100 & 100 & 0 & 100 & 98.46 & . & -1.54 \\
\hline Israel & 100 & 100 & 0 & 100 & 98.57 & 100 & -1.43 \\
\hline Lebanon & 100 & 100 & 0 & 100 & & 89.18 & . \\
\hline Malaysia & & 95 & 2.5 & 97.5 & 99.25 & 93.57 & 1.75 \\
\hline $\begin{array}{l}\text { Iran (Islamic Republic } \\
\text { of) }\end{array}$ & 91 & 93 & 3.5 & 96.5 & 95.6 & 90.25 & -0.9 \\
\hline Korea Re & . & 92 & 4 & 96 & 93.38 & 100 & -2.62 \\
\hline Jordan & 98 & 91 & 4.5 & 95.5 & 91.83 & 85.86 & -3.67 \\
\hline Pakistan & 83 & 90 & 5 & 95 & 92.48 & 72.71 & -2.52 \\
\hline Uzbekistan & 89 & 89 & 5.5 & 94.5 & 90.52 & 69.15 & -3.98 \\
\hline India & 68 & 86 & 7 & 93 & 89.13 & 81.49 & -3.87 \\
\hline Kazakhstan & 86 & 86 & 7 & 93 & 89.49 & & -3.51 \\
\hline Thailand & 81 & 85 & 7.5 & 92.5 & 90.16 & 92.01 & -2.34 \\
\hline Philippines & 87 & 85 & 7.5 & 92.5 & 90.58 & 82.25 & -1.92 \\
\hline Nepal & 69 & 84 & 8 & 92 & 88.9 & 69.08 & -3.1 \\
\hline Syrian Arab Republic & 79 & 79 & 10.5 & 89.5 & & 82.29 & $\dot{.}$ \\
\hline Oman & 77 & 79 & 10.5 & 89.5 & & 97.83 & . \\
\hline Sri Lanka & 68 & 78 & 11 & 89 & 83.37 & 100 & -5.63 \\
\hline Indonesia & 71 & 78 & 11 & 89 & 84.28 & 80.72 & -4.72 \\
\hline Kyrgyzstan & & 77 & 11.5 & 88.5 & 82.03 & 65.65 & -6.47 \\
\hline China & 70 & 77 & 11.5 & 88.5 & 83.76 & 93.73 & -4.74 \\
\hline Bangladesh & 71 & 75 & 12.5 & 87.5 & 81.45 & 72.24 & -6.05 \\
\hline Viet Nam & 72 & 73 & 13.5 & 86.5 & 80.48 & 79.66 & -6.02 \\
\hline Turkmenistan & & 71 & 14.5 & 85.5 & 78.96 & 72.28 & -6.54 \\
\hline Yemen & 69 & 69 & 15.5 & 84.5 & 75.2 & 64.9 & -9.3 \\
\hline Mongolia & 62 & 62 & 19 & 81 & 72.75 & 69.79 & -8.25 \\
\hline Tajikistan & & 58 & 21 & 79 & 68.25 & 78.9 & -10.75 \\
\hline $\begin{array}{l}\text { Lao People's Democratic } \\
\text { Republ }\end{array}$ & & 37 & 31.5 & 68.5 & 53.95 & 70.37 & -14.55 \\
\hline Cambodia & & 34 & 33 & 67 & 51.84 & & -15.16 \\
\hline
\end{tabular}

Source: Author's calculations based on regression models

From the above table, it is clear that a number of countries will miss the water target; however, in most cases, the gap between what is likely to be 
achieved and the MDG target is less than 5 per cent of population. The shortfall in terms of gap between the target and what is likely to be achieved is greater than 5 per cent for 8 countries, namely, Bangladesh, Viet Nam, Turkmenistan, Yemen, Mongolia, Tajikistan, Lao PDR and Cambodia.

Forecast with regard to sanitation target presents a grim picture. The sanitation target is unlikely to be met in most of the countries in the AsiaPacific region. In many countries, the gap between the estimated coverage and MDG target ranges from 10 to 25 per cent of population.

Studies of benefits of water and sanitation improvements such as those by Both Hutton and Haller (2004) and Rijsberman (2004) suggest that benefit-cost ratios for water and sanitation programmes lie in the region of 3 to 4.5. However, a significant share of such benefits is from the positive health impacts and reduced child mortality. The ADB study, however, indicates that convenience benefits are likely to form the major share of benefits of water and sanitation improvement programmes. The message from such studies is that to maximise benefits from water and sanitation programmes, it is essential that improvement takes place on all components of the package, namely, access to water, access to sanitation, and hygiene behaviour and awareness. The forecasts presented here suggest that while Asia region countries will continue to make a significant progress in improving access to water, full benefits in terms of health impacts may not be realised unless sanitation target is also given a high priority. 
Table 2: Forecast of progress with access to sanitation 2015

\begin{tabular}{|c|c|c|c|c|c|c|c|}
\hline & $\begin{array}{l}\text { Access to } \\
\text { sanitation } \\
\% \text { of pop } \\
1990 \\
\end{array}$ & $\begin{array}{l}\text { Access to } \\
\text { sanitation } \\
\% \text { of pop } \\
2000\end{array}$ & $\begin{array}{l}\text { Addl \% of } \\
\text { population } \\
\text { to be } \\
\text { provided } \\
\text { sanitation } \\
\text { to meet } \\
\text { MDG (half } \\
\text { of } 100 \\
\text { minus } \\
\text { san2000) }\end{array}$ & $\begin{array}{l}\text { MDG } \\
\text { target }\end{array}$ & $\begin{array}{l}\text { Projection } \\
1 \text { for } 2015 \\
\text { based on } \\
\text { model S1 } \\
\end{array}$ & $\begin{array}{l}\text { Projection } 2 \\
\text { for } 2015 \\
\text { based on } \\
\text { model S2 }\end{array}$ & $\begin{array}{l}\text { Gap } \\
\text { (projection2 } \\
\text { minus } \\
\text { MDG) }\end{array}$ \\
\hline Israel & 100 & 100 & 0 & 100 & 100 & 98.82 & -1.18 \\
\hline Japan & 100 & 100 & 0 & 100 & & 98.79 & -1.21 \\
\hline Kyrgyzstan & . & 100 & 0 & 100 & 100 & 97.7 & -2.3 \\
\hline Thailand & 80 & 99 & 0.5 & 99.5 & 100 & 100 & 0.5 \\
\hline Jordan & . & 93 & 3.5 & 96.5 & 96.27 & 93.72 & -2.78 \\
\hline Sri Lanka & 70 & 91 & 4.5 & 95.5 & 99.12 & 97.27 & 1.77 \\
\hline Oman & 83 & 89 & 5.5 & 94.5 & . & 94.68 & 0.18 \\
\hline $\begin{array}{l}\text { Iran (Islamic } \\
\text { Republic of) }\end{array}$ & 83 & 84 & 8 & 92 & 89.51 & 88.6 & -3.4 \\
\hline Iraq & 81 & 80 & 10 & 90 & & 80.86 & -9.14 \\
\hline $\begin{array}{l}\text { Syrian Arab } \\
\text { Republic }\end{array}$ & 76 & 77 & 11.5 & 88.5 & & 86.13 & -2.37 \\
\hline Philippines & 54 & 73 & 13.5 & 86.5 & 83.49 & 82.4 & -4.1 \\
\hline Myanmar & 21 & 73 & 13.5 & 86.5 & & 77.62 & -8.88 \\
\hline Kazakhstan & 72 & 72 & 14 & 86 & 77.48 & 77.57 & -8.43 \\
\hline Bhutan & . & 70 & 15 & 85 & & 71.56 & -13.44 \\
\hline Korea Re & . & 63 & 18.5 & 81.5 & & 77.7 & -3.8 \\
\hline Turkmenistan & & 62 & 19 & 81 & 66.75 & 66.63 & -14.37 \\
\hline Mongolia & . & 59 & 20.5 & 79.5 & 65.62 & 64.72 & -14.78 \\
\hline Maldives & . & 58 & 21 & 79 & & 63.93 & -15.07 \\
\hline Uzbekistan & 58 & 57 & 21.5 & 78.5 & 67.37 & 65.63 & -12.87 \\
\hline Pakistan & 38 & 54 & 23 & 77 & 65.3 & 62.52 & -14.48 \\
\hline Tajikistan & . & 53 & 23.5 & 76.5 & 64.77 & 62.63 & -13.87 \\
\hline Indonesia & 46 & 52 & 24 & 76 & 69.07 & 67.58 & -8.42 \\
\hline Bangladesh & 23 & 48 & 26 & 74 & 63.32 & 61.09 & -12.91 \\
\hline China & 23 & 44 & 28 & 72 & 59.72 & 60.67 & -11.33 \\
\hline Fiji & & 43 & 28.5 & 71.5 & & 60.73 & -10.77 \\
\hline Viet Nam & 22 & 41 & 29.5 & 70.5 & 61.4 & 60.02 & -10.48 \\
\hline Timor-Leste & & 33 & 33.5 & 66.5 & & 38.66 & -27.84 \\
\hline India & 12 & 30 & 35 & 65 & 46.63 & 46.03 & -18.97 \\
\hline $\begin{array}{l}\text { Lao People's } \\
\text { Democratic } \\
\text { Republic } \\
\end{array}$ & & 30 & 35 & 65 & 47.4 & 44.86 & -20.14 \\
\hline Yemen & 21 & 30 & 35 & 65 & 47.08 & 43.45 & -21.55 \\
\hline Nepal & 12 & 27 & 36.5 & 63.5 & 45.81 & 44.11 & -19.39 \\
\hline Cambodia & & 16 & 42 & 58 & 33.24 & 31.88 & -26.12 \\
\hline
\end{tabular}

Source: Author's calculations based on regression models 


\section{Financing water and sanitation improvement: The role of aid}

The benefits of water and sanitation improvements include private benefits which accrue mainly to the households gaining such access and public good benefits from health impacts, reduced morbidity, improvement in school attendance by children. While two main domestic sources of water and sanitation sector investments are government funds and investment by consumers ${ }^{2}$, the two main international sources of finance throughout the 1990s were aid and loans. According to Rijsberman (2004:511), 80-90 per cent of current funding in water and sanitation sector comes from domestic funding, much of this from public sector. According to the Camdessus Panel Report: "In the mid-1990s the breakdown of financial sources was estimated to be: domestic public sector $65-70 \%$, domestic private sector 5\%, international donors $10-15 \%$ and international private companies 10-15\%." (Winpenny,2003: 6).

Water and sanitation sector portfolio during the period 1990-2001, based on data available from the Credit Reporting System of the OECD is presented in Appendix Table A3. CRS data pertains to commitments rather than actual disbursals. It is likely that the actual amount of investment based on disbursement is smaller than the figures indicated here. Throughout the period, approximately $\$ 900$ million to $\$ 1$ billion of aid was committed by donors to water and sanitation sector world-wide ${ }^{3}$. While the total amount of aid has remained more or less constant, the number of recipients increased from about 60 in early 1990s to 100 towards the end of the decade. The average magnitude of aid given to a country has thus gradually decreased from about \$ 40 million to around \$ 30 million. Loan financing has increased significantly. It is important to

\footnotetext{
2 In some Asian countries, where public water supply is unreliable or unavailable, some individual consumers invest substantial sums of money making alternative arrangements, such as in terms of wells, tube-wells. Apart from investments to increase quantity, there is also the issue of investments to improve the quality of water, such as UV filtration systems. While better-off consumers 'exit', the poor do not have the exit option. A detailed case study is reported in Anand,2007.

3 According to Camdessus Panel Report (Winpenny,2003:23): “The share of aid to water supply and sanitation in total ODA remained relatively stable in the 1990s at $6 \%$ of bilateral and $4-5 \%$ of multilateral ODA. In recent years, total aid allocations to the water sector have averaged about $\$ 3$ billion a year. An additional $\$ 1-1.5$ billion a year is allocated to the water sector in the form of non-concessional lending by the major MFIs." The figures in CRS data re smaller as information for CRS classification is not available for all ODA projects.
} 
note that aid has provided only a small segment of total investment in water and sanitation.

It can be seen from figure 5 below that the composition of financing changed in mid-1990s when the volume of financing for water sector projects through loans increased substantially by mid-1990s. At the beginning of 1990s, water sector loans were approximately around $\$ 1,000$ million (and comparable to the total volume of aid). However, the volume of loans jumped to the highest value of nearly \$3,000 million by 1996 but there after decreased. Asian region countries accounted for approximately $\$ 313$ million per annum of aid, approximately a third of all aid for water and sanitation sector worldwide.

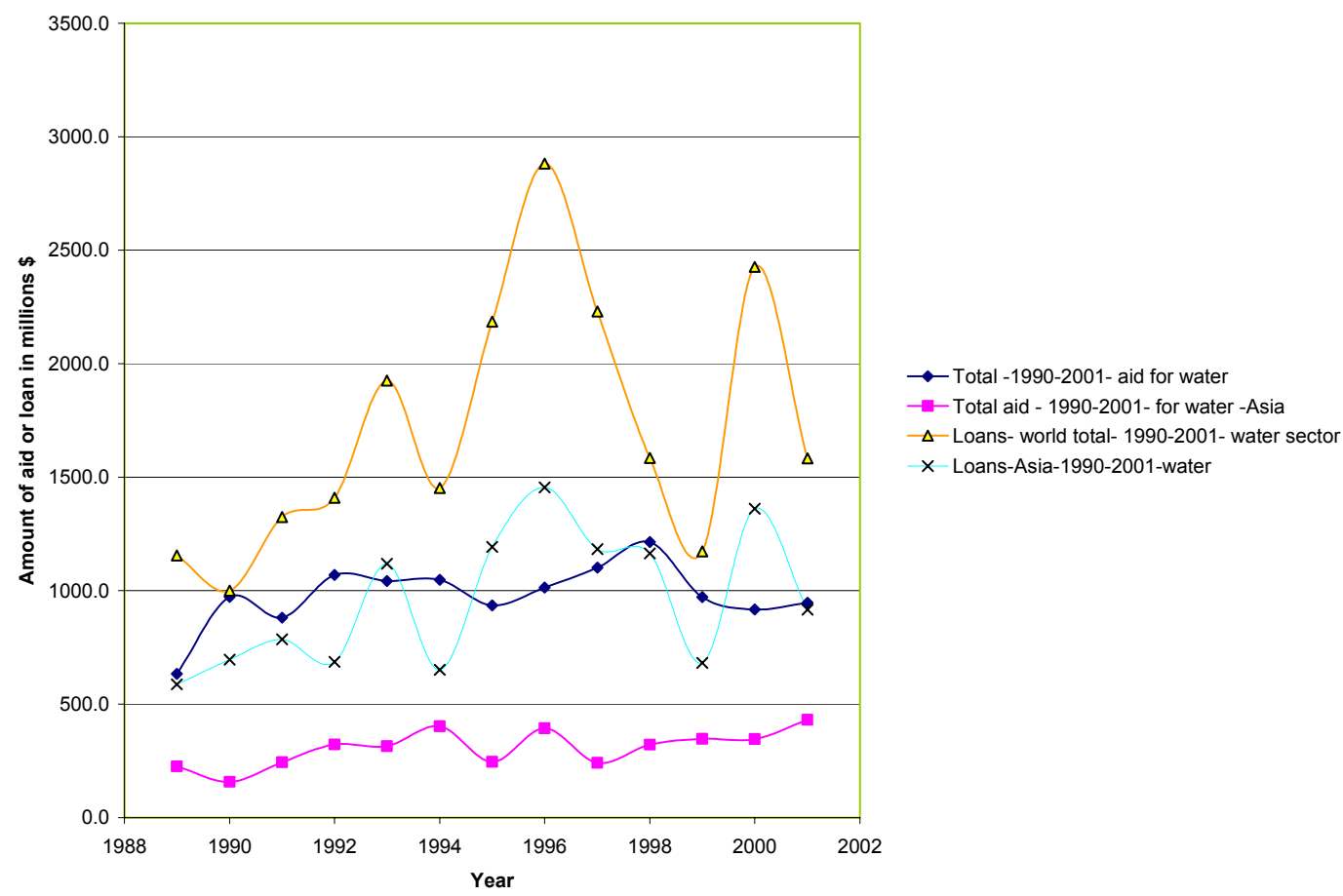

Figure 5: Financing of water and sanitation projects worldwide and in Asia

Loans have been an important source of financing water and sanitation projects in Asia throughout the 1990s - of about \$1,800 million per annum of water and sanitation sector loans worldwide, Asian region accounted for approximately about $\$ 991$ million. From figure 5, it appears that there is no significant difference between global and Asian trends. 


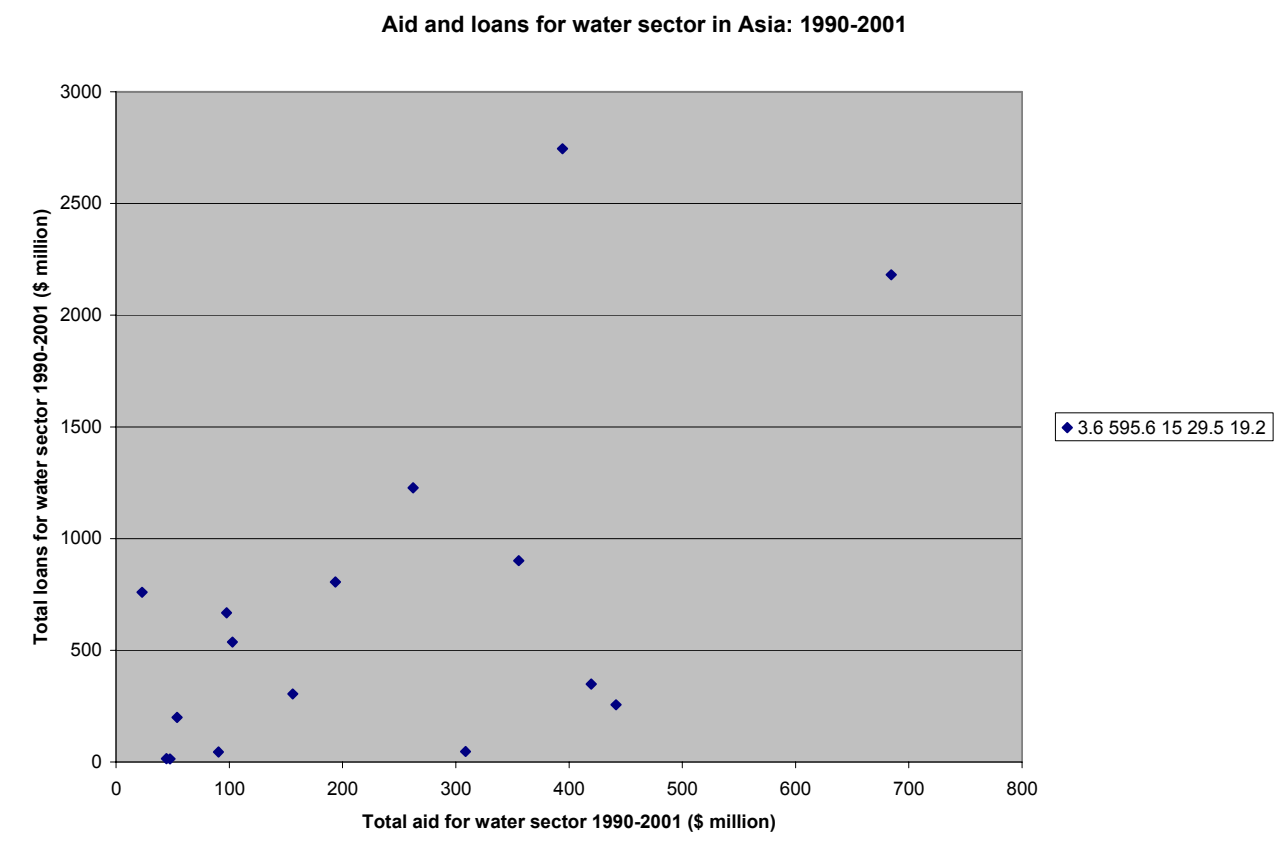

\begin{tabular}{|l|l|}
\hline $\begin{array}{l}\text { Volume of aid - low } \\
\text { Volume of loans - high }\end{array}$ & $\begin{array}{l}\text { Volume of aid - high } \\
\text { Volume of loans - high }\end{array}$ \\
& $\begin{array}{l}\text { India, China, Philippines, } \\
\text { Indonesia, Viet Nam, Jordan }\end{array}$ \\
\hline $\begin{array}{l}\text { (a)Sri Lanka, Pakistan, Nepal, } \\
\text { Syria, Iran, Myanmar } \\
\text { (b)Lao, Uzbekistan, Turkmenistan, } \\
\text { Tajikistan, Bhutan }\end{array}$ & Bangladesh, Yemen \\
$\begin{array}{l}\text { Volume of aid - low } \\
\text { Volume of loans - low }\end{array}$ & $\begin{array}{l}\text { Volume of aid - high } \\
\text { Volume of loans - low }\end{array}$ \\
\hline
\end{tabular}

Figure 6: Aid-loan mix for water sector for countries in Asia 1990-2001

Recall the earlier categorisation into groups 1, 2, and 3 in the previous section. Almost all group 1 countries (where a significantly high proportion of population has access to both water and sanitation) did not 
receive high volume of aid during 1990-2001. Many group 2 countries did receive a significant volume of aid - it is plausible that aid was crucial in some of the countries in increasing coverage in terms of access to water. Some group 1 and group 3 countries are in the bottom-left quadrant in the figure above (low volume of aid-low volume of loans in 1990s). In Sri Lanka and Iran, the proportion of population with access to water and sanitation was already high in 1990. It seems that they were able to maintain this and increase coverage without external funds. The exception is that of Myanmar where the proportion of population with access to water and sanitation increased phenomenally during the 1990s with little aid or external loan financing.

The main messages from figure 1 above seem to be that (a) aid may have played a role in the significant increase in access to water achieved by some countries; (b) if so, a similar strategy may be needed for countries in group 3 where the proportion of population with access to water and sanitation is presently very low; and (c) however, some of the countries that made very significant progress (group 1 and group 2) seemed to have depended on loans rather than aid. Loan financing suggests that in such countries, some extent of water charges or other payments from consumers may have been introduced to raise funds for repayment. Balancing between the goals of financial sustainability on the one hand and that of progressive charges for public services with some form of protection for the poor is a challenge. Aid can play a role in developing such protection mechanisms while loan financing can focus on water sector reform and improving services on the basis of financial viability.

A caveat needs to be highlighted. While aid may be necessary, it appears that the relationship between aid and outcomes is complex. It appears from figure 7 that for the period 1990-2002, the volume of aid does not determine the extent of change in the proportion of population with access to water or sanitation. 


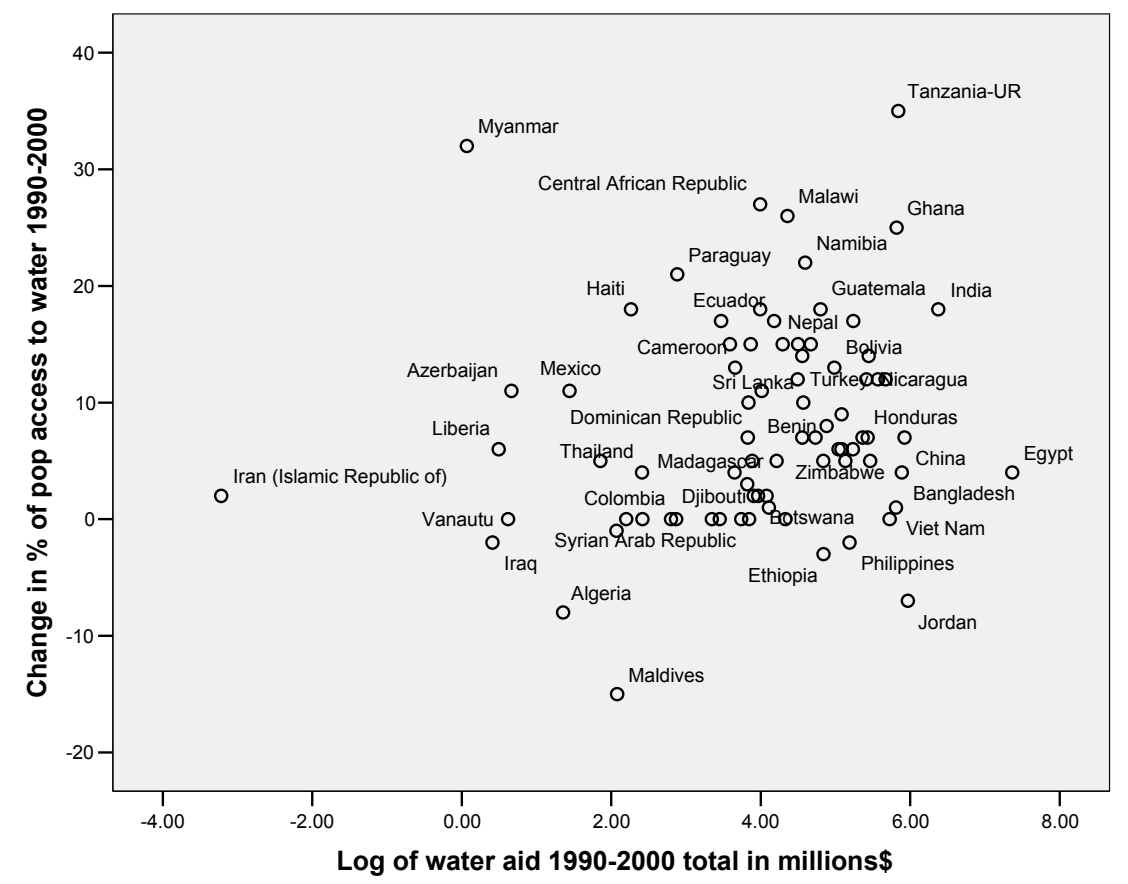

Figure 7: The extent of change in proportion of people with access to water and aid

\section{The role of policy variables}

From the analysis in section 3, it was clear that (a) access to water and sanitation were highly correlated with per capita national income; and (b) starting point matters: improving access is much harder for countries further away from the target where less than 50 per cent of population has access to the services. Here, the role of some of the policy variables is considered briefly.

\section{a. Economic Growth}

Does economic growth matter in increasing access to water and sanitation? There is considerable literature on growth-poverty relationship. In regression model W3, it was seen that economic growth during 1990-2000 was significant and positively associated with proportion of population having access to water in 2000. Since both the dependent and independent variables are in percentage, the parameter is akin to elasticity. This seems to suggest that a 1 per cent increase in GDP per capita growth rate, is likely to lead to an additional 1.3 per cent of population being provided by access to water. This suggests that 
sustained growth in combination with other factors can have an impact on achieving MDG target.

\section{b. Inequality}

Lack of access to water and sanitation is in itself an indicator of inequality in different countries. Therefore, an increase in the proportion of population with access to water and sanitation contributes to a reduction in an aspect of inequality. Though the parameter of Gini coefficient was not significant in many of the regressions, in most cases, it had a negative sign.

\section{c. Social sector spending and public expenditure on health}

This variable was not significant in regressions related to access to water. However, it was highly significant and had a negative sign in some of the regressions related to access to sanitation. This is not surprising, given the link between lack of sanitation and child mortality rate (reported in Anand,2006). Improving access to sanitation is likely to lead a reduction in health impacts in terms of disease burden. Similarly, when only a few people have access to sanitation, high disease burden may lead to high health spending. This highlights the potential negative consequences of missing the sanitation target in most of the countries in Asian region and the urgent need to give a high priority to improving access to sanitation.

\section{d. Privatisation}

In the previous section we saw that many of the high achievers in the Asia region used water sector loans rather than aid to increase access. In some countries in the region, privatisation was a third route to increasing investment in infrastructure. Privatisation of water utilities is likely to have played some role in increasing coverage in some countries, particularly in South East Asia. However, as compared to Latin America, the extent of privatisation of water utilities in Asian region remains low. As per 1997 data (McIntosh and Yniguez,1997), only 2 out of 50 water utilities in Asia were private concessions; in another 10 utilities, private sector was involved in water production. Some utilities use private sector mainly for metering and billing. In countries where there is considerable inequality in access to water or where increasing access in cities requires transfer of water over long distance, privatisation of water utilities tends to be opposed by some groups. If at all pursued, privatisation process 
needs to be managed with care so that the necessary covenants and institutional guarantees are in place to protect the access of the poor. Private sector is more likely to be involved in terms of service contracts while overall management remains in public domain.

Apart from privatisation of water sector, there is another route to mobilising funds, namely, through privatisation of infrastructure (other than water).

Table 3: Infrastructure privatisation proceeds 1990-2001

\begin{tabular}{|c|c|c|c|c|c|}
\hline Region/Country & $\begin{array}{l}\text { Total } \\
\text { infrastructure } \\
\text { privatization } \\
\text { proceeds } \\
\text { 1990-2001 } \\
\text { US \$ million }\end{array}$ & $\begin{array}{l}\text { Proportion } \\
\text { of } \\
\text { population } \\
\text { with } \\
\text { access to } \\
\text { water } 1990\end{array}$ & $\begin{array}{l}\text { Proportion } \\
\text { of } \\
\text { population } \\
\text { with } \\
\text { access to } \\
\text { water } 2002\end{array}$ & $\begin{array}{l}\text { Proportion } \\
\text { of } \\
\text { population } \\
\text { with } \\
\text { access to } \\
\text { sanitation } \\
1990\end{array}$ & $\begin{array}{l}\text { Proportion } \\
\text { of } \\
\text { population } \\
\text { with } \\
\text { access to } \\
\text { sanitation } \\
2002\end{array}$ \\
\hline Latin America \& & & & & & \\
\hline Caribbean & 107844 & 83 & 89 & 69 & 75 \\
\hline East Asia \& Pacific & 32076 & 72 & 78 & 24 & 45 \\
\hline Europe \& Central Asia & 24863 & & & & \\
\hline $\begin{array}{l}\text { Middle East \& North } \\
\text { Africa }\end{array}$ & 3293 & 83 & 88 & 79 & 79 \\
\hline South Asia & 3104 & 71 & 84 & 20 & 37 \\
\hline Sub-Saharan Africa & 2978 & 49 & 58 & 32 & 37 \\
\hline China & 19143 & 70 & 77 & 23 & 44 \\
\hline Malaysia & 6751 & - & 95 & 96 & - \\
\hline Indonesia & 4688 & 71 & 78 & 46 & 52 \\
\hline Thailand & 1816 & 81 & 85 & 80 & 99 \\
\hline India & 1589 & 68 & 86 & 12 & 30 \\
\hline Pakistan & 1236 & 83 & 90 & 38 & 54 \\
\hline Philippines & 973 & 87 & 85 & 54 & 73 \\
\hline Kazakhstan & 779 & 86 & 86 & 72 & 72 \\
\hline Jordan & 508 & 98 & 91 & -- & 93 \\
\hline Oman & 475 & 77 & 79 & 83 & 89 \\
\hline Sri Lanka & 278 & 68 & 78 & 70 & 91 \\
\hline Fiji & 2 & -- & -- & 98 & 98 \\
\hline Vietnam & 1 & 72 & 73 & 22 & 41 \\
\hline
\end{tabular}

Sources: 1. Privatisation proceeds from World Bank Privatisation database.

2. Access to water and sanitation from WHO-UNICEF (2004) 
Data reported in table 3 suggests that it is likely that some of the increased government spending on water and sanitation sector in countries in the region was made possible by the windfall incomes from privatisation of other infrastructure (energy, telecoms, ports). Though this variable is not included in the regressions reported in the Appendix, in other models, it was noted that the parameter of the independent variable measuring the volume of proceeds from privatisation of infrastructure was positive and significant (Anand,2007).

\section{e. Governance and corruption}

All other things remaining constant, corruption can inhibit performance of public services. This is likely to be the case in water sector too. The data on corruption perception index for various countries for the period 1995 onwards is available from Transparency International. CPI Is measured on a scale of 1 to 10 with 1 being most corrupt and 10 being least corrupt. From figure 8 below, it can be seen that there is a positive correlation between CPI score for 1990s and the proportion of population with access to water at the end of that decade.

Some water utilities in the region have taken steps towards increased transparency. Performance indicators are displayed on websites of some organisations, while a small number of utilities have issued 'citizen charters'. However, improving governance of water institutions remains an important issue at macro as well as micro levels. The data of 50 water utilities in Asia (McIntosh and Yniguez, 1997) shows an enormous variation for example in staff per 1,000 connections (from 1.1 in Kaula Lumpur to over 500 in Ulaanbataar). 


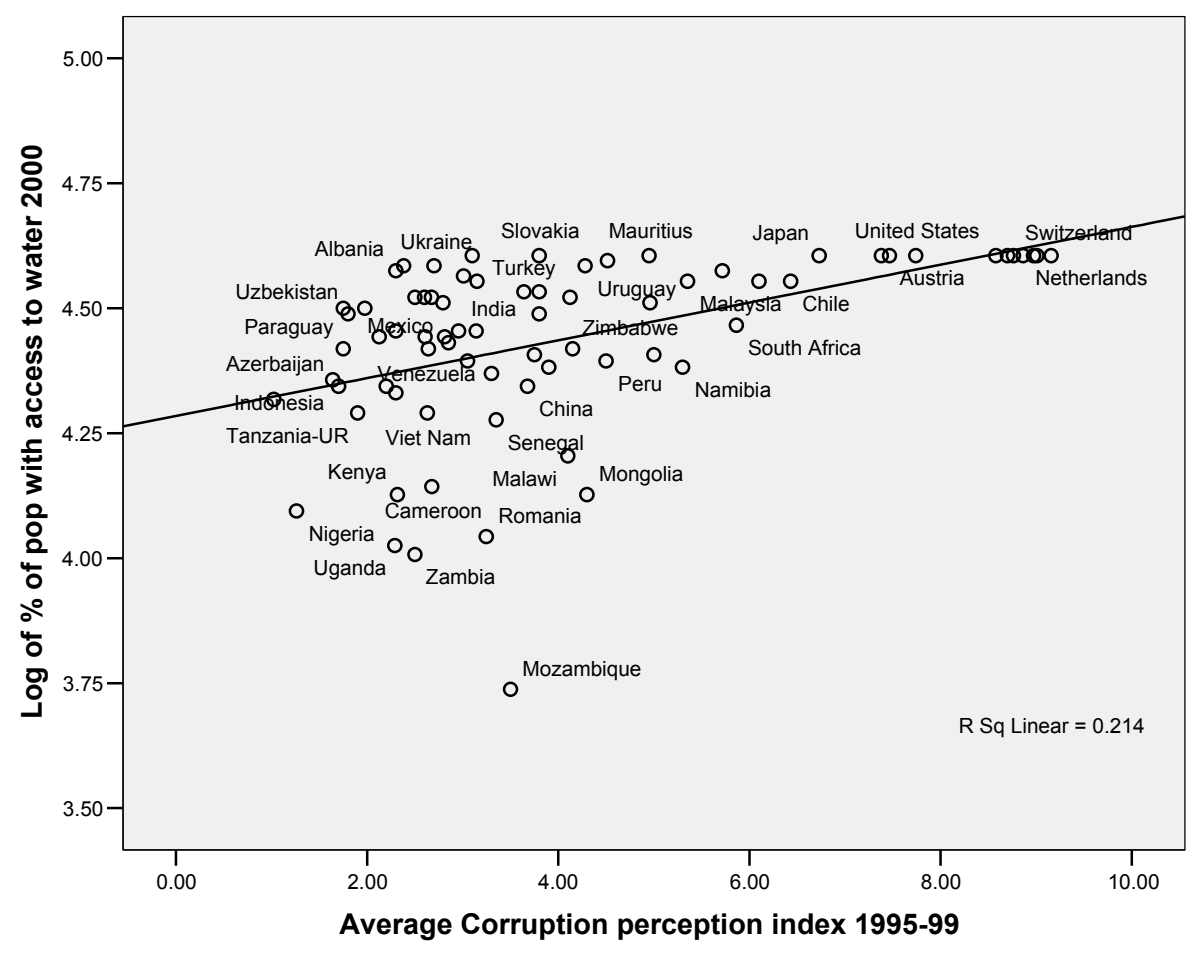

Figure 8: Less corruption - more people have access to water. (Source: Anand,2007)

An alternative route to improving accountability is the approach of 'right to water'. The General Comment 15 of the United Nations (issued in 2002) provides a broader interpretation of the concept of human right and dignity enshrined in the Universal Declaration on Human Rights and on this basis it is argued that a right to water emanates from right to a life of dignity and health. South Africa has been at the fore-front in implementing a right to water approach and some countries in Sub Saharan Africa and Latin America have also introduced provisions towards a right to water. It is early days but my preliminary assessment suggests that a right to water has not yet made a significant difference in increasing the proportion of population with access in the countries where it has been introduced. A right to water is likely to be most effective in countries such as those in group 3 where a large proportion of population does not have access to water and in some countries in group 2 where a substantial majority already has access to water but extending coverage to the remaining population may pose challenges as almost all allocable water resources are committed. 


\section{f. Water resources and 'scarcity'}

Some countries are better endowed than others in terms of water resources. In arid regions, all existing water resources may have already been committed to different uses/property right holders. Increasing the proportion of population with access to water in such regions can trigger local level conflicts between rural and urban groups or between upstream and downstream users ${ }^{4}$. Where such water resources are internal, national level mechanisms may be needed. The issue can be even more challenging when the resource in question is international in scope. (This is examined in the following section.)

In general, in the regression analysis, it was observed that the proportion of population with access to water does not seem related to per capita annual renewable freshwater resources of the country. However, this may not fully reflect the reality. For example, in some Central Asian countries, the statistic of per capita freshwater resources would suggest that such countries have a lot of water resources. However, this is unequally distributed or accessing such water would require substantial investments (for example, due to mountainous terrain). In countries such as Pakistan and India, the amount of freshwater available per capita in some arid regions is less than a third of the national level statistic.

\section{g. Population}

There are two dimensions to a relationship between population and the water and sanitation targets (which are defined in terms of reducing the proportion of population without access). The first dimension is of population size: increasing the proportion of population with access in a populous nation such as China, India, Bangladesh or Indonesia would require significantly large level of resources as compared to a similar level of increase in the proportion of population with access to such services in a less populous nation. Second dimension is that of population growth rate: how fast we need to run to stand still. However, both these variables were not significant in the regressions.

\section{Implications and priorities for regional co-operation}

Water and sanitation improvements may seem to be the unlikely candidates for regional co-operation. However, from the discussion

${ }^{4}$ See Anand,2004a and Anand,2007 on these. 
presented in this paper, it appears that regional co-operation can make a significant contribution in helping countries achieve the MDG target.

a. Priority groupings: We have already seen that countries in the region seem to fall into one of three groups. There is some commonality but there is also difference in policy priorities for these three groups of countries. From the view-point of the region as a whole, there is an urgent need to focus on countries in group 3 (where the proportion of population without access is less than 50 per cent). Aid is likely to be more crucial than loan-financing for these countries.

b. Creating a regional bench-marking system: For countries in group 2 (where a significantly high proportion of population has access to water but access to sanitation remains low and needs to be improved significantly), a regional bench-marking system is likely to be useful. While aid can have some role, loan-financing is likely to contribute to a major share of financing such a programme. At the same time, cost recovery and performance management remain major challenges to improving sanitation. A regional level benchmarking system can help in comparing performance and identifying and sharing best practice. An example of such benchmarking is ADB's work in the past related to Asia's water utilities (McIntosh and Yniguez,1997). What is being suggested here is much more than information dissemination, more akin to a network. For example, the analysis on corruption and access suggests that there is synergy between anti-corruption strategies and achievement of outcomes with regard to water and sanitation services. While much of the anti-corruption work focuses on judicial and regulatory reform, the implications for water sector can be translated and discussed through policy briefs or conferences and publications by such a network. There is also a need for creating an information exchange with regard to approaches to promote accountability and participation, for example, through the use of instruments that can be used by water utilities (such as citizen charters or web portals) and through legal and universal instruments which can be used by the consumers (such as a right to information or a right to water).

c. Facilitating co-operation for international water resources: Many countries in the region share water resources. The most well- 
known cases are: Mekong River Commission established by Cambodia, Lao PDR, Thailand and Viet Nam (1995); Indus Water Treaty between India and Pakistan (1959); Ganga-BrahmaputraMeghna accords (1996) between India and Bangladesh; Jordan water related treaties between Jordan Israel and Occupied Palestine Territories (1995) Tigris-Euphrates-Shatt al Arab related treaties between Syria and Turkey and between Iran and Iraq. There is some evidence to suggest that when two or more countries have a significant share of an international water resource, the proportion of population with access to water increases in countries with stable agreements for such sharing of waters than in countries without stable agreements. For this analysis, I used data available from the Oregon State University's basins at risk programme. These are preliminary findings. Pursuing the development of such treaties and water sharing institutions is likely to contribute to achieving MDG target in particular for Central Asian Countries (Aral Sea basin rivers), Afghanistan, Cambodia, and Lao PDR (which are already party to $\mathrm{MRC}$ ). There is also another message from this analysis to the effect that regional co-operation in the form of sharing of 'software', best practices and know-how is likely to maintaining water and sanitation high on policy agenda and promote convergence in outcomes.

d. For some countries in group 2, and others in group 1, sustaining the significant progress that has already been made is the main issue. Loan financing and privatisation have been the main channels of financing water sector investments in such countries and this is likely to be the case in the future too. A regional network for sharing bet practice with regard to privatisation, identifying thresholds only above which privatisation should be considered a policy mechanism, may be helpful for such countries.

The discussion here highlights the importance of creating a regional infrastructure of 'software' for promoting and sustaining water sector reforms in order to achieve MDG targets. Such networks are clubs that produce regional public goods (Sandler,1998, Anand,2004b). Design of incentive mechanisms is crucial for fostering and maintaining such clubs. 


\section{Limitations and issues for further research}

The discussion in this paper was based mainly on national level aggregate data on access to water and sanitation. There are problems with the definition of access and there is considerable variation in access within each country - for example between rural and urban settlements, within urban areas for those living in slums, and those living close to or far from perennial water resources such as rivers or lakes. Therefore it is important that the MDG target is taken both in letter and in spirit. Some of the relationships examined here may be indicating association due to endogeneity. Countries committed to good governance and reducing inequality tend to be less aid dependent and tend to give high priority to social sector services such as water and sanitation. Therefore, the regressions should be seen as indicative of possible correlations rather than as definitive indicators of causality.

With regard to access, it is clear that definition of such access must be broad enough to include entitlements and opportunity to participate. Therefore, improving access to water and sanitation should not be seen only as a target for technical interventions in the form of pipelines or hard infrastructure but also in terms of the 'soft' infrastructure of collective action institutions to conserve and manage water and promote wellbeing.

PBA/ 7,466 words. 


\section{Appendix}

\section{Regression models used for forecasting}

For models W1 and W2, the dependent variable is the proportion of population with access to water in 2002.

Table A1: Regression models used for estimating access to water

\begin{tabular}{|c|c|c|c|c|c|c|c|}
\hline \multirow[b]{2}{*}{$\begin{array}{l}\text { Description of } \\
\text { independent variable }\end{array}$} & \multirow[b]{2}{*}{$\begin{array}{l}\text { Independent } \\
\text { variable }\end{array}$} & \multicolumn{2}{|l|}{ Model W1 } & \multicolumn{2}{|l|}{ Model W2 } & \multicolumn{2}{|l|}{ Model W3 } \\
\hline & & Parameter & $\begin{array}{l}\text { Collinearity } \\
\text { diagnostic }\end{array}$ & Parameter & $\begin{array}{l}\text { Collinearit } \\
\text { y } \\
\text { diagnostic }\end{array}$ & Parameter & $\begin{array}{l}\text { Colline } \\
\text { arity } \\
\text { diagno } \\
\text { stic }\end{array}$ \\
\hline Constant & & $\begin{array}{l}12.436 \\
(0.687)\end{array}$ & & $\begin{array}{l}16.146^{* * *} \\
(2.645)\end{array}$ & & $\begin{array}{l}-8.539 \\
(-0.499)\end{array}$ & \\
\hline $\begin{array}{l}\text { Access to water as \% } \\
\text { of population in } 1990\end{array}$ & WAT1990 & $\begin{array}{l}0.579^{* * *} \\
(6.341)\end{array}$ & 0.467 & $\begin{array}{l}0.763^{* * *} \\
(16.197)\end{array}$ & 0.646 & --- & \\
\hline $\begin{array}{l}\text { Annual Population } \\
\text { growth rate 1975-2000 }\end{array}$ & POPGROW & $\begin{array}{l}1.670 \\
(0.706)\end{array}$ & 0.443 & --- & & $\begin{array}{l}-1.661 \\
(-0.936)\end{array}$ & 0.669 \\
\hline $\begin{array}{l}\text { Per capita GDP- } \\
\text { average for 1997-1999 } \\
\text { in US\$ in } 2000 \text { prices }\end{array}$ & LogGDPCAP & $\begin{array}{l}2.131 \\
(1.027)\end{array}$ & 0.473 & --- & & $\begin{array}{l}12.310^{* * *} \\
(6.877)\end{array}$ & 0.530 \\
\hline $\begin{array}{l}\text { Per capita GDP } \\
\text { growth rate 1990-2000 }\end{array}$ & ECONGROW & $\begin{array}{l}0.676 \\
(1.000)\end{array}$ & 0.579 & --- & & $\begin{array}{l}1.365^{* * *} \\
(2.567)\end{array}$ & 0.957 \\
\hline $\begin{array}{l}\text { Health expenditure } \\
\text { (public sector) as a } \\
\text { share of GDP average } \\
\text { for } 1998-2000\end{array}$ & HEALTH & $\begin{array}{l}1.010 \\
(0.859)\end{array}$ & 0.453 & $\begin{array}{l}-0.153 \\
(-0.261)\end{array}$ & 0.698 & $\begin{array}{l}0.119 \\
(0.914)\end{array}$ & 0.643 \\
\hline Gini coefficient & GINI & $\begin{array}{l}-0.047 \\
(-0.283)\end{array}$ & 0.374 & $\begin{array}{l}0.123^{*} \\
(1.535)\end{array}$ & 0.817 & --- & \\
\hline $\begin{array}{l}\text { Aid as \% of GDP in } \\
1990\end{array}$ & AID2GDP & $\begin{array}{l}-0.100 \\
(-0.638)\end{array}$ & 0.696 & --- & & --- & \\
\hline $\begin{array}{l}\text { Malnourished people } \\
\text { as \% of population } \\
1990\end{array}$ & MALNURISH & $\begin{array}{l}-0.043 \\
(-0.406)\end{array}$ & 0.725 & --- & & --- & \\
\hline $\begin{array}{l}\text { Fresh water resources } \\
\text { available cubic metres } \\
\text { per capita (Log) }\end{array}$ & LogWATRES & $\begin{array}{l}0.690 \\
(0.783)\end{array}$ & 0.636 & $\begin{array}{l}0.476 \\
(0.408)\end{array}$ & 0.886 & $\begin{array}{l}-1.126 \\
(-1.338)\end{array}$ & 0.948 \\
\hline Adjusted R square & & 0.754 & & 0.845 & & 0.551 & \\
\hline F value & & $\begin{array}{l}13.237 \\
(0.000) \\
\end{array}$ & & 96.305 & & 22.834 & \\
\hline Sample $\mathrm{n}$ & & 37 & & 71 & & 90 & \\
\hline
\end{tabular}

Note: Collinearity diagnostic, tolerance is the percentage of the variance in a given predictor that cannot be explained by the other predictors. When the tolerances are close to 0 , there is high multicollinearity and the standard error of the regression coefficients will be inflated. Variance inflation factor was also estimated but not shown here. A rule of thumb is when the value of collinearity diagnostic is less than 0.5 (or VIF above 2) some degree of collinearity is present. In the above cases, all variables have VIF less than 2 . 
For models S1 and S2, the dependent variable is the proportion of population with access to sanitation in 2002.

Table A2: Results of multiple regression analysis: Dependent variable is access to sanitation (\% of population) in 2000.

\begin{tabular}{|c|c|c|c|c|c|}
\hline & & \multicolumn{2}{|l|}{ Model S1 } & \multicolumn{2}{|l|}{ Model S2 } \\
\hline & & Parameter & $\begin{array}{l}\text { Collinearity } \\
\text { diagnostic }\end{array}$ & Parameter & $\begin{array}{l}\text { Collinearity } \\
\text { diagnostic }\end{array}$ \\
\hline Constant & & $\begin{array}{l}38.573^{* * *} \\
(4.180)\end{array}$ & & $\begin{array}{l}35.392^{* * *} \\
(8.972)\end{array}$ & \\
\hline $\begin{array}{l}\text { Access to } \\
\text { sanitation as \% } \\
\text { of population } \\
\text { in } 1990\end{array}$ & SAN1990 & $\begin{array}{l}0.754^{* * *} \\
(10.325)\end{array}$ & 0.282 & $\begin{array}{l}0.731^{* * *} \\
(16.373)\end{array}$ & 0.282 \\
\hline $\begin{array}{l}\text { Population in } \\
1990 \text { in } \\
\text { millions }\end{array}$ & POP1990 & $\begin{array}{l}-0.00006 \\
(-0.010)\end{array}$ & 0.615 & --- & \\
\hline $\begin{array}{l}\text { Annual } \\
\text { Population } \\
\text { growth rate } \\
1975-2000\end{array}$ & POPGROW & $\begin{array}{l}1.259 \\
(0.495)\end{array}$ & 0.534 & --- & \\
\hline $\begin{array}{l}\text { Per capita } \\
\text { GDP- average } \\
\text { for } 1987-1989 \\
\text { in US\$ in } 2000 \\
\text { prices }\end{array}$ & LogGDPCAP & --- & & --- & \\
\hline $\begin{array}{l}\text { Per capita } \\
\text { GDP growth } \\
\text { rate } 1990-2000\end{array}$ & ECONGROW & --- & & --- & \\
\hline $\begin{array}{l}\text { Health } \\
\text { expenditure } \\
\text { (public sector) } \\
\text { as a share of } \\
\text { GDP average } \\
\text { for 1998-2000 }\end{array}$ & HEALTH & $\begin{array}{l}-1.974^{*} \\
(-1.947)\end{array}$ & 0.528 & $\begin{array}{l}-1.543^{* * *} \\
(2.645)\end{array}$ & 0.618 \\
\hline Gini coefficient & GINI & $\begin{array}{l}-0.103 \\
(-0.792) \\
\end{array}$ & 0.678 & --- & \\
\hline $\begin{array}{l}\text { Aid as \% of } \\
\text { GDP in } 1990\end{array}$ & AID2GDP & $\begin{array}{l}0.091 \\
(0.510)\end{array}$ & 0.651 & --- & \\
\hline $\begin{array}{l}\text { Child } \\
\text { mortality rate } \\
1990\end{array}$ & CMR & $\begin{array}{l}-0.103^{* * *} \\
(-3.367)\end{array}$ & 0.361 & $\begin{array}{l}-0.098^{* * *} \\
(-5.698)\end{array}$ & 0.329 \\
\hline $\begin{array}{l}\text { Adjusted R } \\
\text { square }\end{array}$ & & 0.913 & & 0.936 & \\
\hline F value & & $\begin{array}{l}67.324 \\
(0.000) \\
\end{array}$ & & $\begin{array}{l}466.376 \\
(0.000) \\
\end{array}$ & \\
\hline Sample n & & 45 & & 97 & \\
\hline
\end{tabular}


Table A3: Financing of water and sanitation sector in Asia: 1990-2001 Aid and loans

\begin{tabular}{|c|c|c|c|c|}
\hline Country & $\begin{array}{l}\text { Total water } \\
\text { aid 1990- } \\
2001\end{array}$ & $\begin{array}{l}\text { Average aid } \\
\text { per year }\end{array}$ & $\begin{array}{l}\text { Water sector loans } \\
\text { Total } \\
1990-2001\end{array}$ & $\begin{array}{l}\text { Average loan } \\
\text { 1990-2001 per } \\
\text { annum }\end{array}$ \\
\hline Afghanistan & 7.1 & 1.0 & $\ldots$ & $\ldots$ \\
\hline Bangladesh & 419.6 & 35.0 & 348.7 & 58.1 \\
\hline Bhutan & 15.9 & 2.3 & $\ldots$ & $\ldots$ \\
\hline Cambodia & $\ldots$ & $\ldots$ & 50.9 & 25.4 \\
\hline China & 394.2 & 32.8 & 2745.1 & 228.8 \\
\hline India & 684.4 & 57.0 & 2181.2 & 181.8 \\
\hline Indonesia & 262.3 & 21.9 & 1227.2 & 102.3 \\
\hline Iraq & 2.0 & 0.4 & $\ldots$ & $\ldots$ \\
\hline Israel & $\ldots$ & $\ldots$ & 118.6 & 59.3 \\
\hline Jordan & 441.5 & 44.1 & 256.3 & 28.5 \\
\hline Kazakstan & 9.1 & 1.5 & 29.5 & 14.7 \\
\hline Kyrgyz Rep. & 6.2 & 1.2 & 15.0 & 15.0 \\
\hline Laos & 90.4 & 8.2 & 45.0 & 11.2 \\
\hline Lebanon & 53.9 & 5.4 & 199.5 & 22.2 \\
\hline Malaysia & 4.7 & 0.9 & 595.6 & 198.5 \\
\hline Maldives & 8.1 & 2.0 & $\ldots$ & $\ldots$ \\
\hline Myanmar (Burma) & 6.9 & 3.5 & & $\ldots$ \\
\hline Nepal & 156.0 & 13.0 & 304.8 & 50.8 \\
\hline Pakistan & 97.5 & 8.9 & 667.6 & 83.4 \\
\hline Papua New Guinea & 44.5 & 8.9 & 15.3 & 15.3 \\
\hline Philippines & 193.6 & 16.1 & 805.6 & 100.7 \\
\hline Sri Lanka & 102.7 & 8.6 & 536.7 & 48.8 \\
\hline Syria & 47.6 & 7.9 & 13.6 & 13.6 \\
\hline Tajikistan & 0.3 & 0.1 & 3.6 & 3.6 \\
\hline Thailand & 22.9 & 2.3 & 759.6 & 126.6 \\
\hline Timor-Leste & 17.0 & 4.2 & & $\ldots$ \\
\hline Turkmenistan & 1.4 & 0.3 & $\ldots$ & $\ldots$ \\
\hline Uzbekistan & 11.6 & 2.3 & 19.2 & 9.6 \\
\hline Viet Nam & 355.6 & 29.6 & 901.2 & 100.1 \\
\hline Yemen & 308.6 & 25.7 & 47.2 & 15.7 \\
\hline Total- Asia & 3765.4 & 313.8 & 11892.1 & 991.0 \\
\hline Average - Asia & 199.8 & 16.6 & 457.4 & 100.4 \\
\hline World total & 12112.1 & 1009.3 & 21175.3 & 1764.6 \\
\hline
\end{tabular}

Source: Author's calculations based on data from OECD-CRS. 


\section{References}

Anand P.B. (2007) Scarcity, entitlements, and the economics of water in developing countries, Cheltenham: Edward Elgar.

Anand P.B. (2006) The Millennium Development Goal 7: An assessment of progress with respect to water and sanitation-Legacy, Synergy, Complacency or Policy?, WIDER Research Paper RP 1 of 2006, Helsinki: UNU/WIDER.

Anand P.B. (2004a) Water and identity: An analysis of the Cauvery River Dispute, BCID- Research Paper number 3, Bradford Centre for International Development, University of Bradford, available from URL < http://www.brad.ac.uk/acad/bcid/research/papers/Paper3.pdf>

Anand P.B. (2004) Financing the provision of global public goods, World Economy, 27,2,215-237.

Asian Development Bank (2006) Asia Water Watch 2015: Are countries in Asia on track to meet target 10 of the Millennium Development Goals? Manila: Asian Development Bank.

Hutton G. and Haller L. (2004) Evaluation of the costs and benefits of water and sanitation improvements at the global level, Geneva: World Health Organisation.

McIntosh A., and Yniguez C. (1997) Second Water Utilities Data E3ook: Asian and Pacific Region, Asian Development Bank, Manila.

Rijsberman F. (2004) Sanitation and access to clean water, chapter in Lomburg B.(ed) Global crises, global solutions, Cambridge: Cambridge University Press.

Sandler, T. (1998) Global and Regional Public Goods: A Prognosis for Collective Action, Fiscal Studies, 19 (3): 221-47.

United Nations Development Programme (2005) Health, dignity, and development: What will it take?, UN Millennium Project Task Force on Water and Sanitation, London: Earthscan. 
Winpenny J. (2003) Financing water for all: Report of the world panel on financing water infrastructure, chaired by Michael Camdessus, Washington DC: World Water Council and Global Water Partnership.

WHO-UNICEF (2004) Meeting the MDG Drinking Water and Sanitation Target: A mid-term assessment, Geneva: WHO-UNICEF Joint Monitoring Programme.

END 